\title{
Integrated Fuzzy Analytic Network Process And 0-1 Goal Programming Technique For Enterprise Resource Planning (Erp) Software Selection
}

\author{
Bulanık Analitik Ağ Süreci ve 0-1 Hedef Programlama Entegrasyonu ile \\ Kurumsal Kaynak Planlama (Erp) Yazılımı Seçimi
}

Muhittin SAGNAK ${ }^{1}$

Yigit KAZANCOGLU² https://orcid.org/0000-0002-0799-0348

https://orcid.org/0000-0001-9199-671X

\begin{abstract}
Enterprise Resource Planning (ERP) is a software system incorporating all business functions with regard to systems approach. Global competition forces enterprises to lower costs, reduce inventories, improve quality, and provide better customer service. Therefore, it is important for enterprises to integrate their business functions through the selection and implementation of appropriate ERP software. However, there are three managerial problems existing in this decision process, related respectively with the evaluation of criteria and alternatives, the vagueness within the evaluation process, and the multiple goals and constraints of the company. In this study, in order to select the most appropriate ERP software, the multiple criteria decision-making method (MCDM) is combined with 0-1 goal programming in order to present the combination of linear programming and a MCDM. This combination takes into account not only the need to hire expert opinion for strategic decisions such as ERP selection, but also the limited resources available to enterprises. Also, due to the fuzzy nature of the problem, the MCDM technique, Analytic Network Process (ANP), is combined with fuzzy logic; therefore, fuzzy analytic network process (FANP) is integrated with 0-1 goal programming. The reason for employing FANP is its potential to facilitate the transfer the expert opinion within a network concept.
\end{abstract}

Keywords: ERP Selection, Multiple Criteria Decision-Making, Fuzzy Analytic Network Process, 0-1 Goal Programming

\section{ÖZET}

Kurumsal Kaynak Planlaması (KKP), işletmenin bütün fonksiyonlarını sistem yaklaşımına göre bir araya getiren bir yazılım sistemidir. Küresel rekabet, işletmeleri, maliyetleri düşürmeye, stokları azaltmaya, kaliteyi yükseltmeye ve daha iyi müşteri hizmetleri sağlamasına zorlar. Bu nedenle, işletmelerin, uygun KKP yazılımının seçimi ve uygulanması yoluyla işletme fonksiyonlarını entegre etmeleri önemlidir. Ancak, bu karar sürecinde mevcut üç yönetsel sorun vardır. Birincisi, kriterler ve alternatiflerin değerlendirilmesi ile ilgilidir, ikincisi değerlendirme sürecindeki belirsizlikle ilgilidir ve üçüncüsü, şirketin çoklu amaçlarını ve kısıtlarını dikkate almakla ilgilidir. Bu çalışmada, en uygun KKP yazılımının seçimine karar vermek için doğrusal programlama ve çok kriterli karar verme (ÇKKV) kombinasyonunu sunmak için, ÇKKV yöntemi, 0-1 hedef programlama ile birleştirilmiştir. Bu kombinasyon, yalnızca KKP seçimi gibi stratejik kararlar için uzman görüşünü alma ihtiyacını değil, aynı zamanda işletmeler için mevcut sınırlı kaynakları da dikkate alır. Ayrıca, problemin bulanık doğasından dolayı, ÇKKV tekniği Analitik Ağ Süreci (AAS) bulanık mantık ile birleştirilmiş, bulanık analitik ağ süreci (BAAS) ise 0-1 hedef programlama ile bütünleştirilmiştir. BAAS kullanmanın nedeni, bir ağ konsepti içinde uzman görüşünün aktarılmasına izin verme potansiyelidir.

Anahtar Kelimeler: KKP Seçimi, Çok Kriterli Karar Verme, Bulanık Analitik Ağ Süreci, 0 - 1 Hedef Programlama 


\section{INTRODUCTION}

The increasing use of internet and communication technologies is rendering organizations more complex, interrelated, and extensive worldwide (Cil et al., 2005). Due to intense international competition and very short product lives, it is essential that organizations have the capacity to coordinate large amounts of external information in order to react to the extremely active international market (Karaarslan and Gundogar, 2009). The complexity of organizational problems is expected to contribute to increase in the future; hence, the decision process should consider not only economic, but also social and environmental issues (Cil et al., 2005).

Supply chain, production cycle, and the inventory are the areas in which organizations can decrease their total cost. In addition, the organizations aim to increase product diversity, achieve more precise delivery dates, reduce inventories to a minimum, decrease throughput times, and coordinate supply and production more effectively (Liao et al., 2007; Shankarnarayanan, 2000; Xiuwu et al., 2007). In line with these aims, Yazgan et al. (2009) described Enterprise Resource Planning (ERP) as incorporated commercial information software system integrating all business functions, such as production planning, procurement, sales, finance/accounting, and human resources. The ERP software system aims to satisfy the requirements of each department by allowing the integration of all business functions, and acting as a single system. Although ERP works as integrated interface embodied by several software applications, rather than being a single piece of software, it is also a methodology (Kahraman et al., 2010).

ERP software system is indispensable for enterprises today, allowing them to support organizational strategies, ensure information flow, and improve the performance (Hoermann et al., 2011). It arises from material requirements planning (MRP) and manufacturing resource planning systems (Haddara, 2014; Olson et al., 2012), and is comprised of a central database that includes the organizations' transactions with the help of various functional modules which are production, logistics, marketing, sales, material management, human resources, and finance (Bravo \& Santana, 2010). Moreover, ERP systems enable better productivity and working quality through the standardization and simplification of processes (Maditinos et al., 2011).
ERP points up the consolidation of the information flow associated to main functions of the firm (Chang et al., 2008). Many organizations use ERP systems to gain competitive advantage by providing the integration of all functional areas, and informing users about realtime applications. However, while some organizations benefit from ERP systems, many others fail, and either give up the system, or go bankrupt (Verville et al., 2007).

According to the extensive global study conducted by AMR Research, $67 \%$ of medium-to-large companies use ERP, $21 \%$ have evaluated the potential solutions, and remaining $12 \%$ do not use it. Since a growing number of companies are employing ERP systems, system implementation and upgrades are specified as top priority according to the surveys directed by Morgan Stanley and Deloitte \& Touche/IDG Research Services Group (Haddara, 2014). Moreover, according to the report entitled "Global ERP Software Market Size, Industry Analysis, Trends, Opportunities, Growth and Forecast, 2013-2020" by Chaudhari and Ghone (2015) from Allied Market Research, the global ERP market is expected to reach $\$ 41.69$ billion in sales by 2020 , registering a compound annual growth rate of $7.2 \%$ during the period of 2014-2020.

Generally, there are three steps for building an effective ERP system, which are selection, implementation, and use. The selection of appropriate software is the first step and the most important success factor for ERP implementation (Forslund and Jonsson, 2010). In other words, an ERP adoption process includes the selection and establishment of appropriate ERP software, the examination of the compliance with the system, and the management of organizational change (Aloini et al., 2012). While implementing an ERP system, the selection of the proper software is a major issue. ERP software provides change in arrangement of an organization through the integration of all functions of business which employ database management, and which improve the efficiency of the organization's applications. Herein, the approved multiple criteria decision-making (MCDM) methods are the most effective in the process of determining the most appropriate ERP software (Ayag and Ozdemir, 2007).

ERP selection is also a type of investment; therefore, during the appraisal and selection of ERP package, it is necessary to consider both financial and non-financial factors, such as total cost, supplier's proficiency, supplier's reputation, risks, benefits, implementation 
time, and strategic suitability (Ahn and Choi, 2008; Badri, 2001; Pan and Jang, 2008). Nonetheless, the selection of inappropriate ERP software may devolve the system and deteriorates the performance of the company (Aloini et al., 2012), and may cause failure for organizations to benefit from ERP implementations in which they have heavily invested (Davenport, 2000; Umble et al., 2003). Below are five trends seen in the least successful enterprise software implementations (Krigsman, 2010):

1. Lack of software fit.

2. Unrealistic implementation expectations.

3. Lack of executive buy-in and support.

4. Propensity to customize software rather than leverage standard functionality.

5. Lack of ERP implementation expertise.

The selection of appropriate ERP software that complies with the needs and abilities of the companies is a critical and complicated problem due to the important role it plays in today's organizations (Kilic et al., 2014). The ERP selection problem requires incorporating all business functions, taking into consideration many different criteria. The importance of the criteria may vary and this situation implies that the criteria are not generally equally weighted. Thus, it is important to consider the interdependencies existing among the criteria and alternatives within a network approach.

Business life and uncertainty are inextricably linked; therefore, the evaluation and selection of an ERP system includes an unlimited number of problems (Wei et al., 2005). The evaluation of the alternatives involves both qualitative and quantitative criteria; therefore, it is not always possible to use crisp values in comparisons. Thus, there are two stages in which vagueness or fuzziness is inherent; the comparison of the criteria, and the evaluation of alternatives.

The management aims to achieve multiple goals at the same time. These aims may even contradict each other. Similarly, there are multiple constraints affecting the company. In order to reflect real life conditions, it is essential to account for and deal with these multiple goals and constraints.

Hence, there are three problems in ERP selection from managerial point of view:

- the need to evaluate the criteria alternatives by considering the interdependencies existing among the decision criteria and alternatives
- the vagueness present in the decision process,

- the multiple goals and constraints of

management,

Thus, there is a need to overcome these three problems with a method that will allow combining the multiple and even contradictory management goals and constraints, clarifying the vagueness present in the evaluation process, and evaluating the alternatives by giving in depth analysis through understanding interdependencies of the criteria.

Therefore, in order to overcome these problems, this paper offers an integrated method using fuzzy analytic network process (FANP) with 0-1 goal programming in order to present the combination of linear programming and a MCDM with an analytical approach.

In this study, the ERP software selection is investigated as one of the major problems in ERP management. Therefore, the MCDM method is integrated with 0-1 goal programming in order to present the combination of linear programming and MCDM. This combination is employed as it allows for the hiring of expert opinion for strategic decisions such as ERP selection, consequently, Fuzzy ANP is combined with 0-1 goal programming. Fuzzy ANP is utilized due to the fuzzy nature of the problem, and its potential to allow the transfer of expert opinions within a network concept. 0-1 goal programming is employed due to companies' resource limitations. In the literature, there is no study integrating FANP and 0-1 goal programming techniques for ERP software selection process. The major contribution of this research is the approach of applying the integrated Fuzzy ANP and goal programming approach to ERP software selection process.

The remainder of the paper is structured as follows. First, the literature related to multi criteria decisionmaking for ERP software selection is presented. Then, there is an explanation of the methodology, which includes the fuzzy set theory, fuzzy Analytic Network Process, and goal programming, following there is a description of the proposed model which combines fuzzy ANP and goal programming are explained. The application, analysis, data preparations, and findings are outlined in next section. The last section contains a discussion of future research directions.

\section{LITERATURE REVIEW}

The methods used for the selection of ERP or other information system include scoring, mathematical 
programming, and multiple criteria decision analysis (Karsak and Ozogul, 2009). Lin et al. (2007) provide a complete critique of software selection applications.

In their work, Umble et al. (2003) pointed out various factors to implement ERP successfully. Those factors are data accuracy, the clear understanding of strategic goals, excellent project management, an implementation team, commitment from top management, focused performance measures, organizational change management, and extensive education and training.

Teltumbde (2000) introduced a new methodological analysis integrating Analytic Hierarchy Process (AHP) and nominal group technique. Similarly, by using AHP, Wei et al. (2005) presented a framework which maintains the goals and strategies of organization, determines the appropriate dimensions, and establishes common patterns to assist group decision-making.

Bernroider and Koch (2000) compared large and small organizations regarding to the selection of appropriate ERP software. Ayag and Ozdemir (2007) proposed a fuzzy ANP approach which takes into account both quantitative and qualitative factors during appraisal of ERP software alternatives. In their work, Sen and Baracli (2010) presented a decision support system to get identify software requirements, specify the criteria, and to find the relative importance of the criteria. To achieve this, they employed a fuzzy quality function deployment (QFD) technique in order to decide whether or not non-functional requirements in the literature are in coordination with functional requirements in the selection of appropriate ERP software.

Karsak and Ozogul (2009) presented a new integrated approach using quality function deployment (QFD), fuzzy linear regression, and 0-1 goal programming for ERP system selection. The model employs QFD fundamentals to consolidate the company demands, ERP characteristics, and the interactions of ERP characteristics.

Wei and Wang (2004) used fuzzy average method and fuzzy integral value ranking for more organized and standard evaluation of ERP alternatives through a hierarchical attribute structure. In their recent study, Bernroider and Stix (2006) proposed an approach that integrated the utility ranking method and data envelopment analysis (DEA) to overcome the restrictions of DEA.

Gurbuz et al. (2012) examined the evaluation of four ERP software alternatives through an integrated
MCDM procedure. They used Analytic Network Process (ANP) to identify the relative weights of criteria, and determined the conjunctive and disjunctive behaviors with Choquet integral $(\mathrm{Cl})$ and Measuring Attractiveness by a Categorical Based Evaluation Technique (MACBETH).

Haddara (2014) presented a case study of ERP selection, using weighted scoring simple multiattribute rating technique (SMART). The method involved developing process maps for critical processes of organizations, which were then used to explore the level of convenience of ERP software alternatives with those process maps.

Kilic et al. (2014) made a study about the ERP selection problem for Turkish Airlines. Firstly, they conducted brainstorming sessions to identify the criteria for ERP selection process before using fuzzy Analytic Hierarchy Process (FAHP) to obtain the relative importance of the criteria. Finally, alternatives were ranked with Technique for Order Preference by using Similarity to Ideal Solution (TOPSIS) method.

In their study, Kilic et al. (2015) performed an ERP selection application for small-and-medium sized enterprises in Istanbul, Turkey. They integrated two multiple criteria decision-making techniques, Analytic Network Process (ANP) and Preference Ranking Organization Method for Enrichment Evaluations (PROMETHEE) in order to improve the examination of the ERP selection problem. They identified the weights of each criterion through ANP, and with the help of these criteria weights, ranked the alternatives by PROMETHEE.

Kazancoglu and Burmaoglu (2013) used TODIM method for ERP selection process of a hot dip galvanizing firm. Cruz-Cunha et al. (2016) employed AHP for selection of ERP system for Portuguese organizations. Gupta and Naqvi (2017) proposed a framework for implementing the critical success factors to ERP selection process, and used Fuzzy TOPSIS for numerical example.

Cakir (2016) proposed a robust framework for ERP selection in which after calculating the weights with fuzzy linguistic preference relations (FLPR), he found the rankings of different alternatives through fuzzy TOPSIS.

Ranjan et al. (2016) attempted to establish a framework for systematic ERP selection process. The criteria were weighted with AHP, and the selection 
process included Social Networking, Mobility Analytics, and Cloud Computing.

Haddara (2018) hired a simple multi-attribute rating technique (SMART) for the ERP selection process. Temur and Bolat (2018) used cloud-based design optimization (CBDO) to analyze a large number of criteria; the findings were compared with findings of hesitant fuzzy analytical hierarchy process (HFAHP). Noureddine and Oualid (2018) integrated the theoretical findings and practical recommendations to demonstrate a methodology for ERP selection process.

As shown in the literature review, no study in ERP selection literature can provide a solution to the three problems stated in the introduction. As an example of the multiple goals and constraints of the company, no study in the literature has considered the resource limitations of the companies regarding the ERP software selection, representing a gap in the literature. However, there are studies focusing on individual problems. Fuzzy logic-based studies contribute to overcoming the problem of the vagueness. While ANP based studies are capable of reflecting the expert opinions with a network approach, they neglect the multiple goals and constraints of the company. Goal programming be unable to deal with the vagueness, and is not capable either of weighting criteria or evaluating alternatives like MCDM. Thus, the need arises for an integrated method that can propose a solution to all three aspects. Therefore, in this study, it is aimed to involve not only MCDM, but also the 0-1 goal programming in order to take into consideration the resource limitations of the companies.

\section{METHODOLOGY}

\subsection{Fuzzy Sets Theory}

Decision-makers experience uncertainties in the decision-making process due to the subjective manner of their judgments. To deal with this subjectivity and vagueness in human judgment, Zadeh (1965) introduced the fuzzy set theory to demonstrate the use of linguistic terms in facilitating a decision process. In the theory, mathematical operators and programming are also allowed to apply to the fuzzy domain. A class of objects with a continuum of grades of membership is called a fuzzy set. Characteristic function is used to assign a grade of membership (from zero to 1 ) to each object and this grade characterizes fuzzy sets. If a fuzzy set is represented by a symbol, then a tilde " $~$ " is placed above the symbol (Zadeh, 1965).

There are various fuzzy membership functions. In this paper, triangular fuzzy numbers are used. A triangular fuzzy number (TFN), $\tilde{M}$, is shown in Figure 1 .

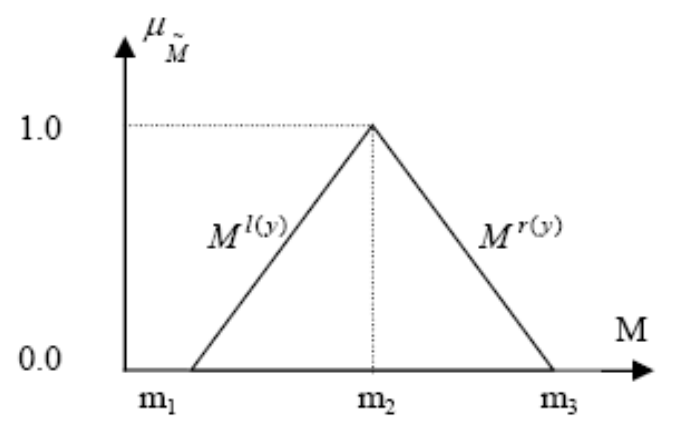

Figure 1: A triangular fuzzy number

A triangular fuzzy number is indicated as $\left(l_{i j^{\prime}} m_{i j^{\prime}} r_{i j}\right)$. The parameters $I_{i j^{\prime}} m_{i j^{\prime}} r_{i j}$ respectively refer the smallest possible, the most likely, and the largest possible values that characterize a fuzzy event.

\subsection{Fuzzy Analytic Network Process}

\subsubsection{Analytic Network Process Method}

The Analytic Network Process (ANP) is the most commonly-used approach for decision-making analysis. Proposed by Saaty (1996), it is formed as a network, rather than the hierarchy used in Analytic Hierarchy Process (AHP). Under AHP, the decisionmaking process is broken down into a top-down linear relationship with independent criteria at each level (Meade \& Sarkis, 1999). However, in ANP, there is a relationship between the clusters (outer dependence) themselves, and the criteria within the clusters (inner dependence). In other words, the criterion for a cluster may affect any criterion in same cluster, or any other cluster (Onut et al., 2009). The main aim is to identify the overall importance weights of all criteria.

Hierarchy may be an inappropriate structure for defining a decision problem in which higher-level clusters are dependent on lower-level clusters (Saaty, 1996). A network system is preferred to a hierarchy when there is feedback between clusters. Saaty (1996) suggested using AHP when the alternatives or criteria are independent, and ANP when dependent. The differences of the structures of hierarchies and networks can be seen in Figure 2. 


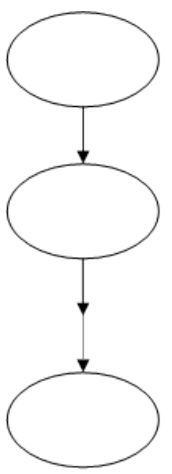

(a)

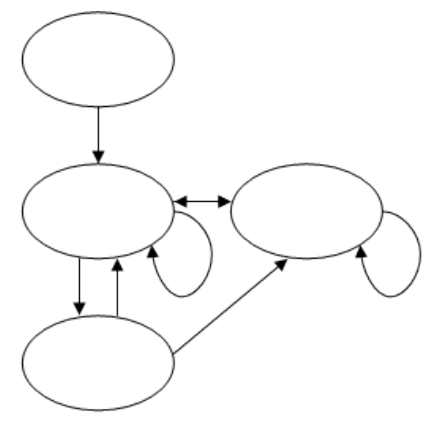

(b)
Figure 2: Structural difference between a hierarchy and a network (a) a hierarchy (b) a network (Chung et al., 2005).

The process of modelling contains three major steps (Onut et al., 2009):

Step 1: Pairwise comparisons and priority vectors: in ANP, as in AHP, pairwise comparisons are used to identify the connections and priorities between the criteria and clusters. The clusters and the criteria within each cluster are compared pairwise, based on internal and external dependencies (Chung et al., 2005). Decision-makers weigh the two clusters or two criteria based on their relative importance regarding upperlevel cluster or criterion. Decision makers indicate their assessments using Saaty's scale (Saaty, 1980), which allows the determination of the relative weights by representing judgments in linguistic terms, as equally important (E), moderately more important (MM), strongly more important (SM), very strongly more important (VSM), and extremely more important (EM). The linguistic terms are then converted into numerical values, $1,3,5,7,9$, respectively and the intermediate values $2,4,6$, and 8 are used to reflect compromise between these. The relative importance of the criterion $i$ to criterion $j$ is indicated by a score of $a_{i j}$ i.e., $a_{i j}=w / w_{j}$. A reciprocal value is found by comparing inversely, that is, $a_{i j}=1 / a_{j i}$ indicating that criterion $j$ is more important than criterion $i$ (Onut et al., 2009).

The pairwise comparison matrix, $A$, is defined as follows:

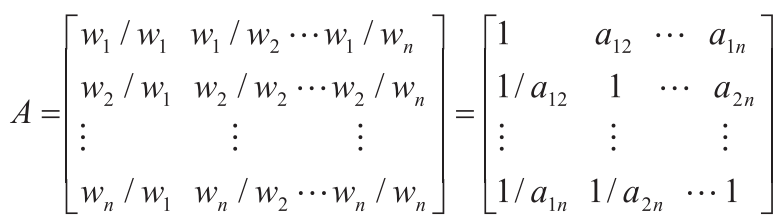

Likewise, in AHP, an eigenvector (local priority vector), w, is calculated by following equation:

$$
A \times w=\lambda_{\max } \times w
$$

where $\lambda_{\text {max }}$ is the biggest eigenvalue of matrix $A$.

Step 2: Initial supermatrix formation: As stated by Saaty (1996), a supermatrix is a concept similar to Markov chains process. Saaty (2001) argued that a supermatrix approach was appropriate for reflecting network relationships, and finding the criteria weights. A supermatrix is a segmented matrix in which each matrix part incorporates a relationship (Meade and Sarkis, 1999). Let the clusters of a decision system be $C_{k}, k=1, \ldots, n$, and each cluster $k$ has $m_{k}$ criteria, indicated by $e_{k 1}, e_{k 2}, \ldots, e_{k m_{k}}$ A standard supermatrix is shown as follows (Lee et al., 2008):

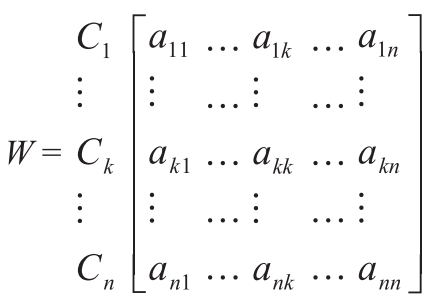

For example, $a_{k 1}$ block shows the relative importance of cluster $k$ regarding cluster 1 ; in other words, it symbolizes the effect of cluster $k$ on each of the cluster 1 (Chung et al., 2005).

Step 3: Weighted Supermatrix formation: An eigenvector is acquired by pairwise comparison of the row criterion with the column criterion. The weighted supermatrix is obtained by weighing the supermatrix by multiplying the first entry of the respective eigenvector with all elements in the first block of that column, second entry with second block, and so on (Chung et al., 2005).

The limit supermatrix, which has the same form with weighted supermatrix, is obtained by taking power of weighted supermatrix to limiting powers in order to sustain the cumulative influence of each criterion on every other criterion interacted (Saaty and Vargas, 1998). The final priorities of all criteria can be found by normalizing each block of the limit supermatrix, in which all the columns are same (Chung et al., 2005).

\subsubsection{Fuzzy ANP: Fuzzy Extension of ANP}

In this study, fuzzy logic is integrated to ANP methodology. Triangular fuzzy numbers are used in order to constitute the pairwise comparison matrices. Fuzzy ANP conforms to the relationships between 
clusters and criteria using supermatrices to calculate the relative importance weights (Onut et al., 2009).

Although Saaty's (1980) scale of 1-9 has the advantages of simplicity and convenience, decisionmakers experience uncertainties because of the subjective manner of their judgments; therefore, pairwise comparison matrices are constructed by using triangular fuzzy numbers $(\mathrm{l}, \mathrm{m}, \mathrm{r})$ in which $l \leq m \leq r$. The parameters $l, m$, and $r$ indicate the smallest possible value, the most likely value, and the most promising value, respectively. The fuzzy matrix is shown as follows (Onut et al., 2009).

$\widetilde{A}=\left(\begin{array}{cccc}\left(a_{11}^{l}, a_{11}^{m}, a_{11}^{u}\right) & \left(a_{12}^{l}, a_{12}^{m}, a_{12}^{u}\right) & \ldots & \left(a_{1 n}^{l}, a_{1 n}^{m}, a_{1 n}^{u}\right) \\ \left(a_{21}^{l}, a_{21}^{m}, a_{21}^{u}\right) & \left(a_{22}^{l}, a_{22}^{m}, a_{22}^{u}\right) & \ldots & \left(a_{2 n}^{l}, a_{2 n}^{m}, a_{2 n}^{u}\right) \\ \vdots & \vdots & \vdots & \vdots \\ \left(a_{m 1}^{l}, a_{m 1}^{m}, a_{m 1}^{u}\right) & \left(a_{m 1}^{l}, a_{m 1}^{m}, a_{m 1}^{u}\right) & \ldots & \left(a_{m n}^{l}, a_{m n}^{m}, a_{m n}^{u}\right)\end{array}\right)$

The $a_{m n}$ reflects the pairwise comparison of criterion $\mathrm{m}$ (row) with criterion $\mathrm{n}$ (column). The pairwise comparison matrix $(\tilde{A})$ is supposed as reciprocal.

$\widetilde{A}=\left(\begin{array}{cccc}(1,1,1) & \left(a_{12}^{l}, a_{12}^{m}, a_{12}^{u}\right) & \ldots & \left(a_{1 n}^{l}, a_{1 n}^{m}, a_{1 n}^{u}\right) \\ \left(\frac{1}{a_{12}^{u}}, \frac{1}{a_{12}^{m}}, \frac{1}{a_{12}^{l}}\right) & (1,1,1) & \ldots & \left(a_{2 n}^{l}, a_{2 n}^{m}, a_{2 n}^{u}\right) \\ \vdots & \vdots & \vdots & \vdots \\ \left(\frac{1}{a_{1 n}^{u}}, \frac{1}{a_{1 n}^{m}}, \frac{1}{a_{1 n}^{l}}\right) & \left(\frac{1}{a_{2 n}^{u}}, \frac{1}{a_{2 n}^{m}}, \frac{1}{a_{2 n}^{l}}\right) & \ldots & (1,1,1)\end{array}\right)$

Logarithmic least squares method, shown below, can be used to estimate the fuzzy priorities (Chen and Hwang, 1992).

$\widetilde{W}=\left(W_{k}^{l}, W_{k}^{m}, W_{k}^{u}\right) \quad k=1,2,3, \ldots, n$

where

$W_{k}^{s}=\frac{\left(\prod_{j=1}^{n} a_{k j}^{s}\right)^{1 / n}}{\sum_{i=1}^{n}\left(\prod_{j=1}^{n} a_{i j}^{m}\right)^{1 / n}}, \quad s \in\{l, m, u\}$

\subsection{0-1 Goal Programming}

In order to consider the resource limitations, the use of fuzzy ANP methodology is extended, and a zeroone goal programming model is created to incorporate the fuzzy ANP weightings as one of its goals:

Minimize $\sum_{k=1}^{K-1} \sum_{i=1}^{m-1} P_{k}\left(d_{i}^{-}+d_{i}^{+}\right)+P_{K}\left(d_{m}^{-}+d_{m}^{+}\right)$

subject to

$$
\begin{aligned}
& \sum_{j=1}^{n} r_{i j} x_{j}+d_{i}^{-}-d_{i}^{+}=R_{i} \text { for } i=1, \ldots, m-1 \\
& \sum_{j=1}^{n} w_{j} x_{j}+d_{m}^{-}-d_{m}^{+}=1 \\
& \sum_{j=1}^{n} x_{j}=1 \\
& x_{j}=0 \text { or } 1 \text { for } j=1, \ldots, n \\
& d_{i}^{-}, d_{i}^{+} \geq 0 \text { for } i=1, \ldots, m
\end{aligned}
$$

where $x_{j}$ are the zero-one variables representing the selection (one), and non-selection (zero) of $j=1, \ldots, n$ choices. There are some deviation variables in Equation 1 , shown as $d_{i}^{-}, d_{i}^{+}$, indicating differences between targeted $i=1, \ldots, m-1$ resource objectives and actual values, and rated by priorities, $P_{k}$, where $k=1,2, \ldots, K . P_{k}$ priorities are listed in order of importance, therefore, $P_{1}>P_{2}>P_{K}$. The $r_{i j}$ in Equation 2 are the parameters for available $R$ resources for each $n$ choice. Fuzzy ANP weightings, whose $d_{m}^{-}$is employed to maximize selection choice, are shown by the $w_{j}$ in Equation 3 (Schniederjans \& Garvin, 1997).

A limited number of studies in the literature employ methodology combining FANP and goal programming. In a relatively recent work, Huang and Hu (2013) proposed an integrated methodology combining FANP and goal programming with De Novo Programming (DNP) for automotive industry supplier selection. Wong (2012) suggested employing FANP-based preemptive integer goal programming as a decision support system in the selection of third party logistics providers. Lee et al. (2010) introduced a methodology combining FANP, QFD, and multi-choice goal programming to select most suitable engineering characteristics.

\section{PROPOSED MODEL}

The proposed model will provide a solution to the three problems mentioned in the previous sections. ANP can be hired to cover interdependencies within a network approach. The interdependencies among the criteria are important in determining the weight of the criteria. On the other hand, fuzzy logic can be used to eliminate the vagueness of the decision process. Finally, to cover the multiple goals and constraints of the company, 0-1 goal programming is recommended, because only one of the ERP alternatives should be chosen. Figure 3 shows the relationships among these techniques. 

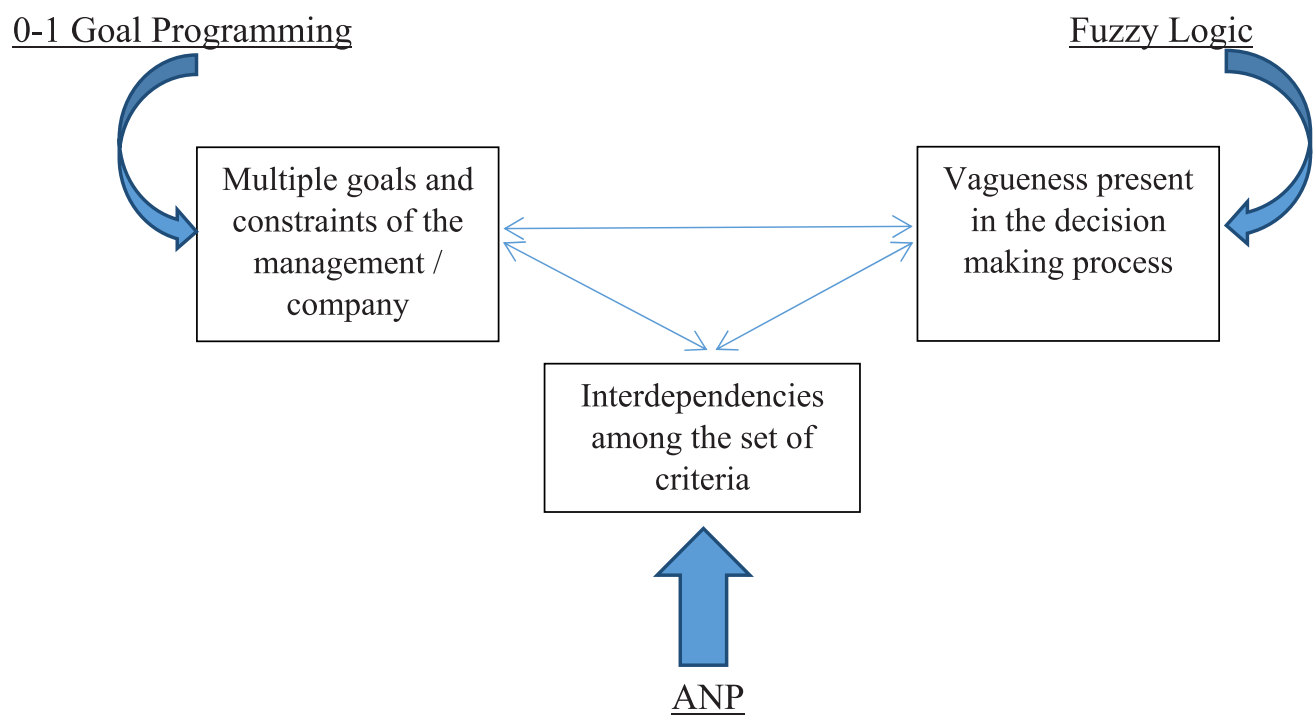

Figure 3: Proposed Model

To sum up, the integrated fuzzy analytic network process and 0-1 goal programming is proposed for the ERP selection problem.

Using one of the wide range of MCDM techniques is a practicable way to make decisions and design a system concerning systems approach. These techniques employs as a decision support system in the decision-making process and system design. The needs and requirements of the decision environment guide managers in determining the most appropriate method for the selection process.

In this paper, it was necessary to evaluate criteria using linguistic variables. Therefore, FANP was considered effective in dealing with the fuzzy nature of the decision process, because it considers both qualitative and quantitative data, and has the potential to allow the transfer of expert opinions within a network concept. In addition, in order to improve the efficiency of the decision-making process, a 0-1 goal programming model was created, taking into consideration the resource limitations and other goals.

The proposed method includes the following seven steps:

1. List the criteria for ERP software selection.

2. Decide the group of experts.

3. Create the pairwise comparison matrices to determine the criteria weights.

4. Calculate the weights of each criterion with Fuzzy ANP.

5. Rank the alternatives in Fuzzy ANP.
6. Create the $0-1$ goal programming model by considering the resource limitations and Fuzzy ANP rankings.

7. Compare the results of Fuzzy ANP rankings with integrated Fuzzy ANP \& goal programming model, and select the best alternative.

Decision-makers may not describe their judgments with discrete values; therefore, fuzzy scales need to be specified. In this study, decision makers used triangular fuzzy numbers, seen in Table 1, to express their preferences in pairwise comparisons.

Table 1: Comparison Scale

\begin{tabular}{|ccc|}
\hline $\begin{array}{c}\text { Linguistic } \\
\text { Variables }\end{array}$ & $\begin{array}{c}\text { Scale of } \\
\text { Fuzzy Number }\end{array}$ & $\begin{array}{c}\text { Scale of } \\
\text { Reciprocal } \\
\text { Fuzzy Number }\end{array}$ \\
\hline Very Poor (VP) & $(1,1,1)$ & $(1 / 1,1 / 1,1 / 1)$ \\
Poor (P) & $(2,3,4)$ & $(1 / 4,1 / 3,1 / 2)$ \\
Fair (F) & $(4,5,6)$ & $(1 / 6,1 / 5,1 / 4)$ \\
Good (G) & $(6,7,8)$ & $(1 / 8,1 / 7,1 / 6)$ \\
Very Good (VG) & $(8,9,10)$ & $(1 / 10,1 / 9,1 / 8)$ \\
\hline
\end{tabular}

\section{APPLICATION}

Step 1: In his work, Teltumbde (2000) suggests a framework using the following criteria: (C1) strategic fitness, (C2) cost, (C3) change management, (C4) implementability, (C5) risk, (C6) business functionality, (C7) vendor credentials, (C8) flexibility, (C9) technology, (C10) benefits. In this study, this set of ten criteria was the basis for determining the best ERP software, as 
it was considered the most appropriate in the ERP selection literature.

Step 2: The application was conducted in a firm manufacturing hot dip galvanizing and steel products in Izmir. Twenty experts from the firm participated in the study; the general manager, the operations manager, the IT manager, the members of IT department, the ERP consultant, and members of the executive board.

Step 3: Firstly, the pairwise comparison matrices should be constructed based on the linguistic terms shown in Table 1. Table 2 shows one expert's judgments.

Table 2: The Judgments of Expert 1

\begin{tabular}{|l|l|l|l|l|l|l|l|l|l|l|}
\hline Expert 1 & C1 & C2 & C3 & C4 & C5 & C6 & C7 & C8 & C9 & C10 \\
\hline C1 & 1 & G & F & VP & P & VP & VP & F & P & VP \\
\hline C2 & & 1 & VP & P & P & F & P & P & VP & P \\
\hline C3 & & & 1 & F & F & P & VP & P & VP & P \\
\hline C4 & & & & 1 & G & F & F & VP & G & F \\
\hline C5 & & & & & 1 & P & F & VP & VP & F \\
\hline C6 & & & & & & 1 & VP & P & P & P \\
\hline C7 & & & & & & & 1 & VP & P & VP \\
\hline C8 & & & & & & & & 1 & VP & P \\
\hline C9 & & & & & & & & & 1 & F \\
\hline C10 & & & & & & & & & & 1 \\
\hline
\end{tabular}

Step 4: Then, these expressions were converted into fuzzy numerical values with a comparison table, seen in Table 1. In order to take into consideration all experts' opinions, the geometric mean of all matrices were calculated.

The fuzzy criteria weights, which can be seen in Table 3, were obtained by employing Step 3.
Table 3: Fuzzy Criteria Weights

\begin{tabular}{|l|c|c|c|}
\hline & I & $\mathbf{~}$ & $\mathbf{u}$ \\
\hline C1 & 0.263 & 0.389 & 0.523 \\
\hline C2 & 0.158 & 0.242 & 0.341 \\
\hline C3 & 0.116 & 0.159 & 0.209 \\
\hline C4 & 0.157 & 0.218 & 0.303 \\
\hline C5 & 0.062 & 0.082 & 0.109 \\
\hline C6 & 0.038 & 0.053 & 0.075 \\
\hline C7 & 0.022 & 0.030 & 0.042 \\
\hline C8 & 0.025 & 0.034 & 0.050 \\
\hline C9 & 0.021 & 0.025 & 0.032 \\
\hline C10 & 0.011 & 0.015 & 0.022 \\
\hline
\end{tabular}

All the fuzzy numerical values were defuzzified using Opricovic and Tzeng's (2003) defuzzification method. Table 4 shows the defuzzified and normalized criteria weights.

Table 4: Defuzzified Criteria Weights

\begin{tabular}{|c|c|}
\hline Criteria & Weights \\
\hline C1 & 0.303 \\
\hline C2 & 0.195 \\
\hline C3 & 0.128 \\
\hline C4 & 0.177 \\
\hline C5 & 0.066 \\
\hline C6 & 0.043 \\
\hline C7 & 0.024 \\
\hline C8 & 0.028 \\
\hline C9 & 0.020 \\
\hline C10 & 0.012 \\
\hline
\end{tabular}

Step 5: The ratings of alternatives can also be found by pairwise comparisons in respect to each criterion. Likewise, in the criteria, the experts compared all alternatives in linguistic terms, and judgments were then converted into numerical values with a comparison table, shown in Table 1. All the ratings of alternatives were fuzzy; all values were defuzzified, as with the case of the criteria. The ratings of alternatives for normalized matrices can be seen in Table 5 .

Table 5: Alternative Ratings according to 10 Criteria

\begin{tabular}{|l|l|l|l|l|l|l|l|l|l|l|}
\hline & C1 & C2 & C3 & C4 & C5 & C6 & C7 & C8 & C9 & C10 \\
\hline A1 & 0.411 & 0.466 & 0.425 & 0.394 & 0.467 & 0.381 & 0.413 & 0.539 & 0.430 & 0.262 \\
\hline A2 & 0.321 & 0.225 & 0.326 & 0.321 & 0.258 & 0.308 & 0.310 & 0.219 & 0.318 & 0.381 \\
\hline A3 & 0.152 & 0.186 & 0.147 & 0.139 & 0.174 & 0.172 & 0.160 & 0.123 & 0.096 & 0.145 \\
\hline A4 & 0.077 & 0.079 & 0.064 & 0.095 & 0.066 & 0.096 & 0.078 & 0.069 & 0.097 & 0.138 \\
\hline A5 & 0.036 & 0.041 & 0.036 & 0.048 & 0.032 & 0.041 & 0.036 & 0.046 & 0.056 & 0.072 \\
\hline
\end{tabular}


Alternative ratings, shown in Table 6 , were calculated by multiplying the normalized criteria weights shown in Table 4, and normalized alternative ratings, in terms of each criterion, shown in Table 5.

Table 6: Alternative Ratings

\begin{tabular}{|l|l|l|}
\hline Alternatives & Result & Decision \\
\hline A1 & 0.425 & $1^{\text {st }}$ Choice \\
\hline A2 & 0.296 & $2^{\text {nd }}$ Choice \\
\hline A3 & 0.156 & $3^{\text {rd }}$ Choice \\
\hline A4 & 0.080 & $4^{\text {th }}$ Choice \\
\hline A5 & 0.040 & $5^{\text {th }}$ Choice \\
\hline
\end{tabular}

Step 6: Normally, FANP assists the decision-making process by providing rankings; therefore, alternative 1 should be selected. In other words, when the FANP is used alone, the selected alternative should be alternative 1 with the highest FANP rating, 0.425 . However, this solution may not be optimal, because the method fails to take into account the various goals in the ERP selection process. These goals are listed below in order of importance.

1. $P_{1}=$ the company aims to limit its budget to $\$ 50000$.

2. $\mathrm{P}_{2}=$ the company aims to limit implementation costs to $\$ 7500$.

3. $\mathrm{P}_{3}=$ the company aims to limit implementation time to 12 hours.

4. $\mathrm{P}_{4}=$ the company aims to satisfy the results of FANP technique, and is not willing to use less than 1 of FANP alternative weights.

Hereunder, the 0-1 goal programming model with FANP weightings and resource limitations appears as follows:

$\operatorname{Min} Z=P_{1}\left(d_{1}^{+}\right)+P_{2}\left(d_{2}{ }^{+}\right)+P_{3}\left(d_{3}^{+}\right)+P_{4}\left(d_{4}^{-}\right)$

subject to

$50000 X_{1}+45000 X_{2}+30000 X_{3}+18000 X_{4}+16000 X_{5}+d_{1}-d_{1}{ }^{+}=50000$

$3500 x_{1}+3000 x_{2}+2800 x_{3}+2000 x_{4}+1200 x_{5}+d_{2}-d_{2}^{+}=7500$

$7 X_{1}+6 X_{2}+5 x_{3}+3 X_{4}+3 X_{5}+d_{3}^{-}-d_{3}^{+}=12$

$0.425 X_{1}+0.296 X_{2}+0.156 X_{3}+0.080 X_{4}+0.040 X_{5}+d_{4}-d_{4}^{+}=1$

$X_{1}+X_{2}+X_{3}+X_{4}+X_{5}=1$

$X_{j}=0$ or 1 ;

$d_{i}, d_{i}^{+} \geq 0$
Table 7 shows the result of $0-1$ goal programming method.

Table 7: 0-1 Goal Programming Results

\begin{tabular}{|l|l|l|}
\hline Alternatives & Result & Decision \\
\hline A1 & 1 & Yes \\
\hline A2 & 0 & No \\
\hline A3 & 0 & No \\
\hline A4 & 0 & No \\
\hline A5 & 0 & No \\
\hline
\end{tabular}

Step 7:The FANP result gives alternative 1 a weight of 0.425 , making it the preferred choice for the company. This choice is supported by the 0-1 goal programming result, which includes both the FANP weighting and the other goals with restrictions; because alternative 1 is the only decision variable to take a value of 1 , it should be selected.

\section{DISCUSSION}

The selection of ERP software is a complex and judgmental decision-making process. The selection of appropriate ERP software that meets the needs and abilities of companies is a critical problem due to the significant role it plays in today's organizations (Kilic et al., 2014). Business life and uncertainty are inseparably linked; therefore, the evaluation and selection of an ERP system has an infinite number of problems (Wei et al., 2005). Without taking an analytical approach, the decision making process may be inconsistent and inflexible. With an appropriate analytical ERP selection process, companies will be able to support organizational strategies, ensure the information flow, achieve more precise delivery dates, reduce inventories to a minimum level, decrease throughput times, and more effectively coordinate supply and production. More generally, the systems approach can integrate the business functions, namely, production, logistics, marketing, sales, human resources, and finance.

There are three managerial problems existing during the ERP selection from managerial point of view;

- the need to evaluate the criteria and alternatives by considering the interdependencies existing within the decision criteria and alternatives

- the vagueness present in the decision process 
- the multiple goals and constraints of management

Thus, there is a need to overcome these three managerial problems with a method that will allow integration of the management's multiple and even contradictory goals and constraints, clarification of the vagueness that is present in the evaluation process, and evaluation of the alternatives through in depth analysis, by considering interdependencies of the criteria.

This paper presents two approaches to the ERP software selection problem: a FANP method, and integrated FANP and 0-1 goal programming method. The fuzzy logic compensates for with the vagueness during the evaluation of criteria and alternatives, while the multiple criteria of ANP permit decisionmakers greater flexibility in data use for the ERP selection process. The FANP methodology was utilized to provide consistency in ranking of ERP software alternatives. Although, according to the FANP result, alternative 1 should be selected due to the highest FANP rating, the multiple goals and constraints were not considered in this approach. Therefore, it is important to consider resource limitations, namely, budget costs, implementation costs, and time needed for implementation. When the FANP is used alone, then the alternative with the highest rating should be selected; however, this solution method fails to take into account company goals or resource limitations in ERP software selection process. Hence, FANP method is used both to find the highest ranking alternative, and the relative $w_{j}$ of alternatives in goal programming model. Therefore, this paper illustrates a combined FANP and goal programming approach to the selection of the best software alternative, to take into account resource limitations.

The integrated FANP and 0-1 goal programming method offers systematic and analytical approach to the ERP software selection problem. It also extends previous research, first, by considering resource limitations, and second, by integrating consistent weightings of judgmental criteria within an optimization process.

Further studies may concentrate on different MCDM applications for ERP selection. 


\section{REFERENCES}

Ahn, B.S. and Choi, S.H. (2008) "ERP system selection using a simulation-based AHP approach: a case of Korean home shopping company" Journal of the Operational Research Society, 59(32): 322-330.

Aloini, D., Dulmin, R. and Mininno, V. (2012) "Risk assessment in ERP projects" Information Systems, 37(3): 183-199.

Ayag, Z. and Ozdemir, R.G. (2007) "An intelligent approach to ERP software selection through fuzzy ANP" International Journal of Production Research, 45(10): 2169-2194.

Badri, M.A. (2001) "A combined AHP-GP model for quality control systems" International Journal of Production Economics, 72(1): 27-40.

Bernroider, E. and Koch, S. (2000) "Differences in characteristics of the ERP system selection process between small or medium sized and large organizations" Proceedings of the Sixth Americas Conference of Information Systems, 10-13 August, Long Beach, CA, 1022-1028.

Bernroider, E.W.N. and Stix, V. (2006) "Profile distance method - A multiattribute decision making approach for information system investments" Decision Support Systems, 42: 988-998.

Bravo, E. and Santana, M. (2010) "Impacto de la implementación de lossistemas de planeamiento de recursosempresariales ERP en el desempeño individual" Americas Conference on Informations Systems, Lima, Perú, 265.

Cakir, S. (2016) "Selecting appropriate ERP software using integrated fuzzy linguistic preference relations - fuzzy TOPSIS method" International Journal of Computational Intelligence Systems, 9(3): 433-449.

Chang, I.C., Hwang, H.G. and Liaw, H.C. (2008) "A neural network evaluation model for ERP performance from SCM perspective to enhance enterprise competitive advantage" Expert Systems with Applications, 35: 1809-1816.

Chaudhari, S. and Ghone, A. (2015) Global ERP Software Market -Size, Industry Analysis, Trends, Opportunities, Growth and Forecast, 2013-2020. Allied Market Research ERP Market Report.

Chen S.J. and Hwang C.L. (1992) "Fuzzy multiple attribute decision making" Lecture Notes in Economics and Mathematical Systems, 375: 289-486.

Chung, S.H., Lee, A.H. and Pearn, W.L. (2005) "Product mix optimization for semiconductor manufactur- ing based on AHP and ANP analysis" International Journal of Advanced Manufacturing Technology, 25: 1144-1156.

Cil, I., Alpturk, O. and Yazgan, H. (2005) "A new collaborative system framework based on a multiple perspective approach: InteliTeam" Decision Support Systems, 39: 619-641.

Cruz-Cunha, M.M., Siva, J.P., Goncalves J.J., Fernandes, J.A. and Avila, P.S. (2016) "ERP Selection using an AHP-based Decision Support System" Information Resources Management Journal, 29(4): 65-81.

Davenport, T.H. (2000) Mission Critical: Realizing the Promise of Enterprise Systems, Harvard Business School Press, Boston, MA.

Forslund, H. and Jonsson, P. (2010) "Selection, implementation and use of ERP systems for supply chain performance management" Industrial Management and Data Systems, 110(8): 1159-1175.

Gupta, R. and Naqvi, S.K. (2017) "A Framework for Applying CSFs to ERP Software Selection: An Extension of Fuzzy TOPSIS Approach" International Journal of Intelligent Information Technologies, 13(2): 41-62.

Gurbuz, T., Alptekin, S.E. and Alptekin, G.I. (2012) "A hybrid MCDM methodology for ERP selection problem with interacting criteria" Decision Support Systems, 54: 206-214.

Haddara, M. (2014) "ERP Selection: The SMART Way" Procedia Technology, 16: 394-403.

Haddara, M. (2018) “ERP systems selection in multinational enterprises: a practical guide" International Journal of Information Systems and Project Management, 6(1): 43-57.

Hoermann, S., Kienegger, H., Langermeier, M., Mayer, M. and Krcmar, H. (2011) "Comparing Risk and Success Factors in ERP Projects: A Literature Review" Americas Conference on Information Systems, Detroit, Michigan, USA, 241.

Huang, J.D. and Hu, M.H. (2013) "Two-stage solution approach for supplier selection: A case study in a Taiwan automotive industry" International Journal of Computer Integrated Manufacturing, 26(3): 237251.

Kahraman, C., Beskese, A. and Kaya, I. (2010) "Selection among ERP outsourcing alternatives using a fuzzy multi-criteria decision making methodology" International Journal of Production Research, 48(2): 547-566. 
Karaarslan, N. and Gundogar, E. (2009) "An application for modular capability-based ERP software selection using AHP method" International Journal of Advanced Manufacturing Technologies, 42: 1025-1033.

Karsak, E.E. and Ozogul, C.O. (2009) "An integrated decision making approach for ERP system selection" Expert Systems with Applications, 36: 660-667.

Kazancoglu, Y. and Burmaoglu, S. (2013) “ERP software selection with MCDM: application of TODIM method" International Journal of Business Information Systems, 13(4): 435-452.

Kilic, H.S., Zaim, S. and Delen, D. (2014) "Development of a hybrid methodology for ERP system selection: The case of Turkish Airlines" Decision Support Systems, 66: 82-92.

Kilic, H.S., Zaim, S. and Delen, D. (2015) "Selecting "The Best" ERP system for SMEs using a combination of ANP and PROMETHEE methods" Expert Systems with Applications, 42: 2343-2352.

Krigsman, M. (2010). "Lessons from ERP Implementation Failures". Retrieved from: http://inforln.com/ wp-content/uploads/2014/05/Focus-Experts-Buying-Guide-for-ERP.pdf

Lee, A.H.I., Kang, H. and Chang, H. (2008) "Evaluating Buyer-Supplier Relationships in HighTech Industry by Analytic Network Process (ANP)" Proceedings of the Service Operations and Logistics, and Informatics, IEEE/SOLI 2008, IEEE International Conference, 12-15 October, Beijing, 2677-2682.

Lee, A.H.I., Kang, H.Y., Yang, C.Y. and Lin, C.Y. (2010) “An evaluation framework for product planning using FANP, QFD and multi-choice goal programming" International Journal of Production Research, 48(13): 3977-3997.

Liao, X., Li, Y. and Lu, B. (2007) "A model for selecting an ERP system based on linguistic information processing" Information Systems, 32: 1005-1017.

Lin, H.Y., Hsu, P.Y. and Sheen, G.J. (2007) “A fuzzy-based decision making procedure for data warehouse system selection" Expert Systems with Applications, 32: 939-953.

Maditinos, D., Chatzoudes, D. and Tsairidis, C. (2011) "Factors affecting ERP system implementation effectiveness" Journal of Enterprise Information Management, 25(1): 60-78.

Meade, L.M. and Sarkis, J. (1999) "Analyzing Organizational Project Alternatives for Agile Manufacturing Processes: An Analytical Network Approach" International Journal of Production Research, 37:241-261.
Noureddine, M. and Oualid, K. (2018) “Extraction of ERP Selection Criteria using Critical Decisions Analysis" International Journal of Advanced Computer Science and Applications, 9(4): 100-108.

Olson, D.L., Van Huy, V. and Tuan, N.M. (2012) "Case of development of a small business ERP consultant knowledge base" Advances in Enterprise Information Systems II, Edited by Charles Møller and Sohail Chaudhry CRC Press.

Onut, S., Kara, S.S. and Isik, E. (2009) “Long term supplier selection using a combined fuzzy MCDM approach: A case study for a telecommunication company" Expert Systems with Applications, 36: 3887-3895.

Opricovic, S. and Tzeng, G.H. (2003) “Defuzzification within a Multicriteria Decision Model" International Journal of Uncertainty, Fuzziness, and Knowledge-Based Systems, 11(5): 635-652.

Pan, M.J. and Jang, W.Y. (2008) "Determinants of the adoption of enterprise resource planning within the technology-organization-environment framework: Taiwan's communications industry" Journal of Computer Information Systems, 48(3): 94-102.

Ranjan, S., Jha, V.K. and Pal, P. (2016) "A strategic and sustainable multi-criteria decision making framework for ERP selection in OEM" International Journal of Applied Engineering Research, 11(3): 1916-1926.

Saaty, T.L. (1980) The Analytic Hierarchy Process. McGraw-Hill, New York.

Saaty, T.L. (1996) Decision Making with Dependence and Feedback: The Analytic Network Process. RWS Publications, Pittsburgh.

Saaty, T.L. and Vargas, L.G. (1998) "Diagnosis with dependent symptoms: Bayes theorem and the analytic hierarchy process" Operations Research, 46(4): 491-502.

Saaty, T.L. (2001) Decision making with dependence and feedback: The Analytic network process (2nd ed.), Pittsburg: RWS Pub.

Schniederjans, M.J. and Garvin, T. (1997) "Using the Analytic Hierarchy Process and multi-objective programming for the selection of cost drivers in activity-based costing" European Journal of Operational Research, 100: 72-80.

Sen, C.G. and Baracli, H. (2010) "Fuzzy quality function deployment based methodology for acquiring enterprise software selection requirements" Expert Systems with Applications, 37: 3415-3426.

Shankarnarayanan, S. (2000) "ERP systems--using IT to gain a competitive advantage" Retrieved from: http://www.angelfire.com/co/troyc/advant.html 
Teltumbde, A. (2000) "A framework for evaluating ERP projects" International Journal of Production Research, 38: 4507-4520.

Temur, G.T. and Bolat, B. (2018) "A robust MCDM approach for ERP system selection under uncertain environment based on worst case scenario" Journal of Enterprise Information Management, 31(3): 405-425.

Umble, E.J., Haft, R.R. and Umble, M.M. (2003) “Enterprise resource planning: Implementation procedures and critical success factors" European Journal of Operational Research, 146: 241-257.

Verville, J., Palanisamy, R. and Bernadas C. (2007) "RP Acquisition Planning: A Critical Dimension for Making the Right Choice" Long Range Planning, 40: 45-62.

Wei, C.C. and Wang, M.J.J. (2004) "A comprehensive framework for selecting an ERP system" International Journal of Project Management, 22: 161-169.
Wei, C.C., Chien, C.F. and Wang, M.J.J. (2005) “An AHPbased approach to ERP system selection" International Journal of Production Economics, 96: 47-62.

Wong, J.T. (2012) "DSS for 3PL provider selection in global supply chain: combining the multi-objective optimization model with experts' opinions" Journal of Intelligent Manufacturing, 23(3): 599-614.

Xiuwu, L., Yuan, L. and Bing, L. (2007) "A model for selecting an ERP system based on linguistic information processing" Information System, 32(7): 1005-1017.

Yazgan, H.R., Boran, S. and Goztepe, K. (2009) "An ERP software selection process with using artificial neural network based on analytic network process approach" Expert Systems with Applications, 36: 9214-9222.

Zadeh, L.A. (1965) "Fuzzy sets" Information Control, 8: 338-353. 